\title{
Introduction: Living in the Ottoman House
}

\author{
Virginia H. Aksan \& Veysel Şimşek*
}

\begin{abstract}
"What is significant about empires in history was their ability to set the context in which political transformation took place. The enticements of subordination and enrichment kept empires in motion, in tension or conflict with each other and other kinds of states. Memories of empire, rejection and fear of empires, and aspirations to make new complex polities inspired and constrained leaders and followers, the ambitious, the indifferent and the compelled."

"For all this time, as Ottoman subjects, our honour and property have been protected by the Sublime State. Our freedom is still intact. The other day when I was in Büyükdere, the British pestered me saying 'come, let's put you under British protection.' I replied that "all my ancestors have always lived with Ottomans. It would be unseemly for us to become something else." From a conversation by Dimitri of Kayseri, a zimmi, overheard in Silivrikapı, Istanbul, July I $840 .{ }^{1}$
\end{abstract}

Biography is back with a vengeance in the writing of history under the guise of the exploration of "identity" in late multi-ethnic imperial settings. We are experiencing an age of tremendous upheaval and angst about the future of the post WWII nation-state which has led in turn to questions about the nature of subjecthood, citizenship and community especially in the pre-modern world, just one reason that the study of the Ottoman Empire has become such a growth industry.

* McMaster University, Canada. This volume is dedicated to the memory of Oktay Aksan, 1934-20I3, affectionately known as "the last Ottoman". Nur içinde yatsin.

I Jane Burbank and Frederick Cooper, Empires in World History: Power and the Politics of Difference Princeton: Princeton University Press, 20IO, p. II. Cengiz Kurl1, Sultan ve Kamuoyu: Osmanl Modernleşme Sürecinde "Havadis Jurnalleri" (I840-I844) (Istanbul: İş Bankası Kültür Yayınları, 2009), 64. 
According to a recent reflection on the subject, twentieth century nationalist histories which cast firm ethnic associations into the early nineteenth century are (or should be) a thing of the past. ${ }^{2}$

Driven by the absolute necessity for ethical precision around subjecthood, and retribution for victimization, our own age has had particular difficulty in penetrating the opacity of survival which characterized all subjects of pre-modern non-western empires. Şuhnaz Yılmaz and İpek Yosmaoğlu comment: "What taints the imperial past is not only the foreign rulers, but the experience of a communal existence that is anathema to the nation state's exigency of clear boundaries and social purity."3

My work has wandered in and out of the question of "Ottomanness" across a couple of decades, starting with a biography of Ahmed Resmi and more recently asking the question "Who was an Ottoman?". ${ }^{4}$ Invited to contribute to an edited volume on biography at the turn of the millennium, I suggested that historians of the Ottoman Empire spend a good deal of time "listening to silence...An Ottoman official or anyone who aspired to Ottomanism, Muslim and non-Muslim, acquiesced in communal silence, accepting the ambiguity of the clichés embodied in Muslim/Ottoman theories of rule about 'justice' or 'tolerance." ' 5 More specifically, how do we comprehend "identities" in the era 1650-1850, when individuals were more likely recognized (or treated empirically as such by historians) as part of collectives (political households, ayans, ulema, court cliques, ethnicities, slaves,

2 Asl Ergul, “The Ottoman Identity: Turkish Muslim or Rum?” Middle Eastern Studies 48:4 (2012). 629-45, an up-to-date look at the literature on the Bzyantine-TurcoOttoman synthesis. The new approaches to non-Muslim minorities can be found most recently in Jens Hanssen, “'Malhamé - Malfamé'”: Levantine Elites and Transimperial Networks on the Eve of the Young Turk Revolution," International Journal of Middle East Studies 43 (20II), 25-48, and Christine Phillou, "Communities on the Verge: Unraveling the Phanariot Ascendancy in Ottoman Governance," Comparative Studies in Society and History 5I:I (2009), I5I-8I.

3 Şuhnaz Yılmaz and İpek Yosmaoğlu, "Fighting the Spectres of the Past: the Dilemmas of Ottoman Legacy in the Balkans and the Middle East," Middle Eastern Studies 44:5 (2008), 677-693.

4 Virginia Aksan, "The Question of Writing Pre-Modern Biographies of the Middle East," in Mary Ann Fay, ed., Auto/Biography and the Creation of Identity and Community in the Middle East (New York: Palgrave, 200I), I9I-200, and Virginia Aksan, "Who was an Ottoman? Reflections on 'Wearing Hats' and 'Turning Turk," in Barbara Schmidt-Haberkamp, ed. Europe und die Türkei in I8. Jahrhundert / Europe and Turkey in the Eighteenth Century (Göttingen: Unipress, 2011), 305-I8.

5 Aksan, "The Question,” I95. 
minorities, women, warriors, guilds, nomads), or regions (northern and southern tier), or even spatial configurations (outsiders, insiders; urban, rural; port cities, interior)? And what to make of the cultural mediators: the converts, renegades, diplomats, missionaries and merchants, populations whose presence in the empire was particularly large in its latter days.

We do have a deepening of the literature, already rich, on the experience of non-Muslims, Jewish and Christian families, who constituted the native Levantine population of Ottoman realms, and whose experience as "Ottomans" was transformed in the period under discussion, a period most acknowledge is the beginning of a new global order. The cultural ramifications of the radical transformation of Ottoman society on Muslim natives, however, is less well developed and overly represented by imaginary Orients and non-native narratives of renegades and adventurers. Until very recently, the native voices which most closely reflected the agenda of the European enlightenment were assumed to represent the majority of Ottoman subjects, and preferred as authorities to those who contested the transformation with their own Christian or Muslim worldviews. This absence and the questions that arise from it have been at the heart of a project called "Ottoman Profiles," which ruefully is still underway after more than a decade.

A number of the contributions in this volume began as discussions at a Great Lake Ottoman Workshop, and then as a panel which I organized for the Sixteenth Century Society and Conference held in Geneva, both in 2009. (represented here by Murat Cem Menguç, Maurits von den Boogert and Christine Isom-Verhaaren). In securing funding for my own project, I proposed organizing a workshop on "Living in the Empire," which would draw on historians who work across the span of the empire to interrogate our understanding of what it took to be a participant in Ottoman society, and how that might have changed post-I700. I wanted to explore ways in which we could articulate Ottoman loyalty and disloyalty in a collapsing world through alternate, and less obvious means of self-expression (library \& textual analysis, milieu, etc.) and without reifying existing stereotypes. What makes these individuals Ottoman? Or subscribe to a notional "Ottomanness"? How did they understand and express their relationship with their imperial overlords in Istanbul? What lends them "authenticity" as Ottoman subjects and/or cross-cultural mediators? What can they tell us about this unique hybridized and by 1840 semi-colonial setting? What can we learn about the circulation of knowledge in a non-western society at the edge of the modern age?

The conference that resulted, "Living Empire: Ottoman Identities in Transition I700-I850," was organized by me and Veysel Şimşek, and held on the campus 
of McMaster University in Hamilton, Ontario, Canada, in April 2012. The call for papers emphasized the desire to expand the scope of our understanding of the period by using materials assembled on those who "lived" empire: not just the lives of the imperial elites, their foreign advisors and detractors, but also those of ordinary people of a variety of ethnic and religious backgrounds, who willingly or unwillingly were Ottoman subjects. We wanted especially to hear from some largely ignored or overlooked Ottoman voices, Muslim and non-Muslim, from the fullest extent of Ottoman territories as possible.

To state the obvious, most of us discovered that very few of our subjects/ authors use the term "Ottoman" about themselves, but many found ways to associate with "sultan-ness," and to connect themselves to sultanic beneficence, perhaps through the ubiquitous contract for service so distinctive to the Ottoman patrimonial state, or joining a network of associations, such as the court bureaucracy, urban and provincial political households, warrior bands, army regiments, guilds, or the Muslim legal or religious circles. The discussion which closed the conference identified a further five clusters of ideas around the experience of living in the empire, with particular focus on the transformative period.

Agency, continuity and legacy are aspects of the drama around the lives we described. Using identity as a category of analysis, we recognized three aspects which affect the way we view our subjects: who the individuals (or collective) were as measured through our contemporary lens; how they might have expressed belonging themselves, and what they were not.

- The redistribution of wealth so prevalent an aspect of Ottoman society of the period had an enormous influence on the reordering of the social hierarchies in our stories: Some thought it possible to discern the evolution of a sort of political contract, or at the very least, a set of negotiations at work as Burbank/Cooper stress in the quotation which opens this introduction.

- Ecology, or the importance of environment, combined with mobility, flexibility and risk, as well as moral codes and state propaganda, were also part of the discussion of survival in this context. Warrior societies on the steppes, in the mountains and on the sea, and later on, the Ottoman regulars in uniforms: gazis/corsairs/deli/bashibozuks were hired guns but served as an important source of labor for the dynasty. When is a kul or conscript not a slave; when is a gazi not a corsair, when is a bashibozuk simply a man without a master? ${ }^{6}$

6 Or even, when is a Christian not a Muslim? as ably demonstrated in a fascinating article by Ariel Salzmann, "A Travelogue Manqué: the Accidental Itinerary of a Maltese 
- Around the question of legitimacy and belonging, we had more questions than answers. How to determine the impact of the projections of sovereignty such as love of ruler and subject; father/son to motherland; ruler of three continents $\&$ the sacred cities to Sunnism; how to observe the transformation from millet to milletism to nationalism. How do we measure change to such projections and arguments about legitimacy??

- Geography and mapping the imaginary space of empire in the lives under study underwrote everything we did. The huge variety of geopolitical space - urban and rural, land and sea, the centrality of the Aegean islands of the Mediterranean, and the Levant - all proved important to our understanding of the genesis or adoption of an Ottoman identity.

- We were left with a question about causality: Is it possible to see change, rupture, different strategies or modes of behavior through the lens of an individual resident in Ottoman territories before 1850 ?

\section{Organization of the volume}

Part one "Ottomans and Turks: Some Initial Thoughts," offers us some provocations. Maurits van den Boogert introduces us to the variables of homo ottomanicus and begins to collect the characteristics of such an animal, noting that the only thing fixed about identity from the Ottoman point of view was the fiscal and legal aspects of residence. Palmira Brummett then takes up the question of Boogert's "Ottoman identity grid" by "seeing" the Ottomans through the lens of European encounters - the narration of the "Grand Turk" and the search for classical antiquity from the sixteenth and seventeenth centuries - when the majority of the encounters were embedded in the networks by which the traveler navigated Ottoman space. Individuals peek through in this context. The difference in the eighteenth century is that the amount of knowledge on the "Turk", written and visual, had exploded, so that categories such as "Janissaries" were clichés. The individual is still effaced. Murat Cem Menguç returns to Aşıkpaşazade's text and its sources to trace

Priest in the Seventeenth Century Mediterranean?" in A Faithful Sea: The Religious Cultures of the Mediterranean Adnan A. Husain and K. E. Fleming, eds., (Oxford: Oneworld, 2007), I49-72.

7 A novel study of the Tanzimat courts and the agency of non-Muslim plaintiffs and litigants is a very good example: Milen V. Petrov, "Everyday Forms of Compliance: Subaltern Commentaries on Ottoman Reform, I864-I868," Comparative Studies in Society and History 46:4 (2004), 730-59. 
the idea of an individual and an evolving sense of Turkishness (or Anatolian-ness) as an argument about historical objectivity in the earliest Ottoman histories.

The second section: "Getting by as an Ottoman," takes us into the world of Ottoman bureaucrats and intellectuals of the $18^{\text {th }}$ century. Kahraman Şakul's Zihni Ismail Pasha's experiments with military technology invite us to consider the very existence of inventors in the Ottoman world, and how his experiments might have been received in a slightly different context such as Italy or Hungary. Orlin Sabev's excursion into Ibrahim Müteferrika asks us to question the labels of convert, Mason, Jew and Muslim as ascribed to the printer as obfuscating autobiography. Fatih Yeşil's deep knowledge of Ebubekir Ratib Efendi is abundantly evident in the weaving of the extraordinary ways in which the Ottoman of Selim III was navigating the superficial waters of edeb while swimming with the currents of reform acquired while in Vienna, a synthesis that evidences the transformation of the "Ottoman" from the sword wielding warrior-administrator to the diligent, world-trotting scribe in the $18^{\text {th }}$ century. Finally, Ethan Menchinger takes on Ahmed Vâsıf's worldview and traces the sources of his notion of causality and change, a genuine philosophy of history. Tracing Ahmed Vâsıf's thoughts in his writings, Menchinger challenges the past and present notion that the Ottoman mentality was blinded by an "Oriental fatalism", and while unique to the period, he argues that such a philosophy of history arose from a context in which the Ottoman bureaucrats were increasingly concerned about political reform and moral responsibility.

The three articles in the third section: "Beyoğlu, Getting by as foreigners and non-Muslims," form the most cohesive set of essays in the volume. Frank Castiglione examines the case of the Pisani dragoman family of the British Embassy in the $19^{\text {th }}$ century, demonstrating just how complicated the legal and personal definitions of subjecthood were. Frederick Pisani thought himself an Ottoman, while Count Alexander Pisani's heirs claimed British citizenship in filing his last will and testament in Britain. Both also laid claim to being Italian. Julia Landweber tells the story of the $18^{\text {th }}$ century murder of a French cook of the French embassy by a Venetian barber of the Italian bailo. The resolution to the case is clearly an example born of the nature of the status of these foreign nationals in Pera, and their changing perceptions about nationality based on their social order. Will Smiley's article involves the tale of putative Greek Orthodox privateers, now Russian "citizens", and their release following the peace treaty of 1792 which stipulated their return to Russia. At various times in their negotiations with the Ottomans, these corsairs called themselves Christian, Muslim, Russian, and Venetians, a fine example of how agency might operate as manpower became more valued. 
Christine Isom-Verhaaren, Tolga Esmer and Veysel Şimşek bring "Defending the Empire" into the discussion in section four. Five corsair captains are analyzed by Isom-Verhaaren through the autobiographical passages to be found in their narratives, bringing us back to the place they thought of as Rum. Esmer takes a closer look at the autobiography of Deli Mustafa (d. 1792), whose curious narrative reveals details about fighting for a living and the identity of an Ottoman soldier of fortune at the turn of the nineteenth century. Esmer further alerts us to the possibility as using such as text as an "ego document", scrutinizing the narrative and self-fashioning strategies aimed at his target audience. Veysel Şimşek focuses on the conscripts of the reformed, European style army, which emerged as a new social group as a result of Ottoman political-military transformation between I820s andi850s. He probes the conscripts' social and ethnic origins, and their responses to their novel, state-imposed identity as the sultan's unwilling fulltime (and likely life-time) soldiers.

The final section of this issue, "Living Empire in the Provinces," provides us with five regional perspectives on Ottomanness. James Reilly argues that alMakki's eighteenth century narrative demonstrates a tension between a Muslim universalism represented by the Ottomans and parochial concerns in the Syrian town of Homs. Dana Sajdi creates mental maps of the place names mentioned by her eighteenth century authors as expressions of their social location, profession, political networks, religiosity or personal ambitions. Charles Wilkins hones in on the life of a Muslim judge and merchant from Aleppo. Using waqf documents from the establishment of a madrasa, Wilkins draws a portrait of a complex individual, servant of the Ottomans, status as a descendant of the prophet, Sufi adherent and patron of the Kurds. Antonis Hadjikyriacou takes us to the island of Cyprus to examine the life of three individuals tied to the Ottoman system as dragoman, tax collector (muhassil) and an Armenian dragoman-merchant. What is intriguing in his piece is the evidence of the long (if erratic) arm of the Ottoman state in the eighteenth century. Fatma Sel Turhan traces the life and death of a popular rebel leader from Bosnia during the I82os and I830s, Hüseyin Kapudan. Turhan analyses his undulating career path in the context of centralization, territoriality and rebellion in Bosnia. The final paper by Darin Stephanov uses Bulgarian kasides recited in local ceremonies to explore the orchestration of a tour by Sultan Abdulmecid to Bulgaria in I846 as part of the new visibility of the sultan, and the construction of official birthday and accession-day celebrations in expression of collective loyalty to the Ottoman monarch. 


\section{Bibliography}

Aksan, Virginia. "The Question of Writing Pre-Modern Biographies of the Middle East," in Mary Ann Fay, ed., Auto/Biography and the Creation of Identity and Community in the Middle East (New York: Palgrave, 200I), I9I-200.

Aksan, Virginia. "Who was an Ottoman? Reflections on 'Wearing Hats' and 'Turning Turk,"” in Barbara Schmidt-Haberkamp, ed. Europe und die Türkei in I8. Jahrhundert / Europe and Turkey in the Eighteenth Century (Göttingen: Unipress, 20II), 305-I8.

Burbank, Jane and Frederick Cooper, Empires in World History: Power and the Politics of Difference (Princeton: Princeton University Press, 20I0).

Ergul, Asli. "The Ottoman Identity: Turkish Muslim or Rum?” Middle Eastern Studies 48:4 (2012). 629-45.

Kırlı, Cengiz. Sultan ve Kamuoyu: Osmanl Modernleşme Sürecinde "Havadis Jurnalleri" (I840-I844) (Istanbul: İş Bankası Kültür Yayınları, 2009).

Hanssen, Jens. "Malhamé - Malfamé”": Levantine Elites and Transimperial Networks on the Eve of the Young Turk Revolution," International Journal of Middle East Studies 43 (2OII), 25-48.

Petrov, Milan V. "Everyday Forms of Compliance: Subaltern Commentaries on Ottoman Reform, I864-I868," Comparative Studies in Society and History 46:4 (2004), 730-59.

Phillou, Christine. "Communities on the Verge: Unraveling the Phanariot Ascendancy in Ottoman Governance," Comparative Studies in Society and History 5I:I (2009), I5I-8I.

Salzmann, Ariel. "A Travelogue Manqué: the Accidental Itinerary of a Maltese Priest in the Seventeenth Century Mediterranean?" in Adnan A. Husain and K. E. Fleming, eds., A Faithful Sea: The Religious Cultures of the Mediterranean (Oxford: Oneworld, 2007), I49-72.

Yılmaz, Şuhnaz, and İpek Yosmaoğlu, "Fighting the Spectres of the Past: the Dilemmas of Ottoman Legacy in the Balkans and the Middle East," Middle Eastern Studies 44:5 (2008), 677-93. 